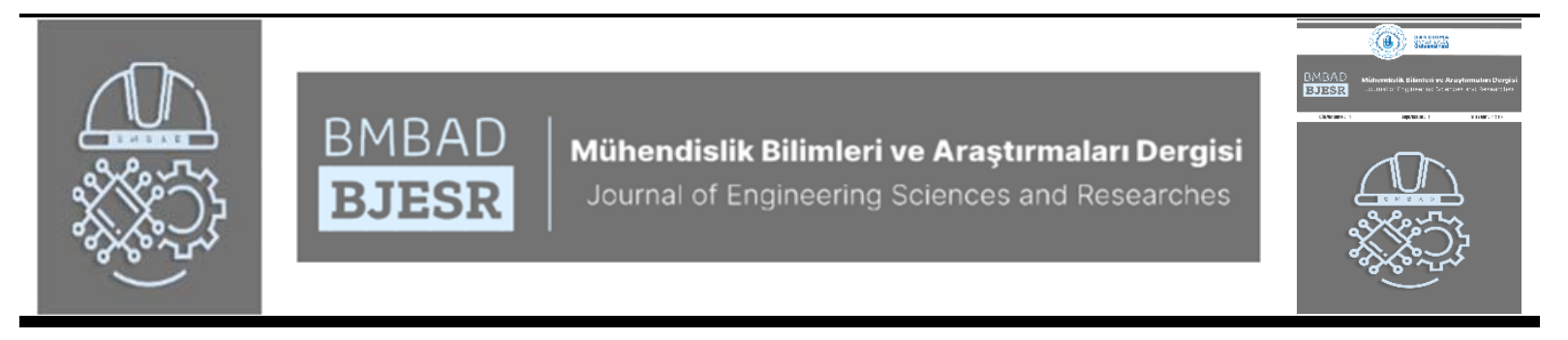

\title{
Application of Intelligent Optimization Techniques to Spectral and Energy Efficiencies in Massive MIMO Systems at Different Circuit Power Levels
}

\author{
Yığın MIIMO Sistemlerde Spektral ve Enerji Verimlilikklerine Farklı Devre Güicü \\ Seviyelerinde Zeki Optimizasyon Tekniklerinin Uygulanması \\ ${ }^{1}$ Burak Kürşat Gül ${ }^{(D)},{ }^{1}$ Necmi Taşpınar $(D)$ \\ ${ }^{1}$ Department of Electrical and Electronics Engineering, Erciyes University, Kayseri, Turkey
}

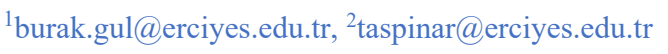

Araştırma Makalesi/Research Article

A R T I C L E I N F O
Article history
Received : 9 March 2021
Accepted : 22 March 2021

Keywords:

Massive MIMO, Spectral Efficiency, Energy Efficiency, Intelligent Optimization Techniques

\section{A B S T R A C T}

In cellular communications, whose usage continues to increase day by day, it is seen as a necessity to increase the area throughput in order to avoid data traffic density problems. For this, it is aimed to increase spectral efficiency by using massive multi-input multi-output systems and also to keep energy efficiency high. It is known that spectral and energy efficiencies can increase with different number of user equipment served in the cell, number of active antennas and values of the transmission power. By using intelligent optimization techniques, optimum combinations of these three variables can be determined and samples with both high spectral and energy efficiencies at the same time can be obtained. In this paper, multi-objective genetic algorithm, multi-objective particle swarm optimization and multi-objective differential evolution algorithm are applied on three different circuit power sets and then results obtained are evaluated.
M A K A L E B İ L G İ S İ

\section{Makale Tarihleri}

Gönderim : 9 Mart 2021

Kabul : 22 Mart 2021

\section{Anahtar Kelimeler:}

Yığın MIMO, Spektral

Verimliliği, Enerji

Verimliliği, Zeki

Optimizasyon Teknikleri

\section{Ö Z E T}

Kullanımı her geçen gün artamaya devam eden hücresel iletişimlerde, trafik yoğunluğu sorunu yaşanmaması adına alan iş çıkarım yeteneğinin artırılması gereklilik olarak görülmektedir. Bunun için yığın çok girişli çok çıkışlı sistemler kullanılarak spektral verimliliğin artırılması ve beraberinde enerji verimliliğin yüksek tutulması hedeflenmektedir. Hücre içerisinde hizmet verilen kullanıcı sayısı, kullanılan aktif anten sayısı ve iletim gücünün çeşitli değerleri için spektral ve enerji verimliliklerinin artabildiği bilinmektedir. Zeki optimizasyon teknikleri kullanılarak bahsi geçen üç değişkene ait optimum kombinasyonlar tespit edilerek spektral ve enerji verimliliklerinin aynı anda yüksek olduğu örnekler elde edilebilmektedir. Bu çalışmada çok amaçlı genetik algoritma, çok amaçlı parçacık sürü optimizasyonu ve çok amaçlı diferansiyel gelişim algoritması üç farklı devre gücü seti üzerinde uygulanmış ve elde edilen sonuçlar değerlendirilmiştir.

(C) 2020 Bandırma Onyedi Eylül Üniversitesi, Mühendislik ve Dağa Bilimleri Fakültesi. Dergi Park tarafindan yayınlanmaktadır. Tüm Hakları Saklıdır. 


\section{INTRODUCTION}

The usage of cellular communication is also becoming widespread with the widespread usage of wireless communication systems, which have managed to become an indispensable part of our daily life thanks to the facilities they provide. The increase in both the number of cellular network users and the amount of data interacted through these communication systems is very rapid. This increase in data usage is so high that the area throughput (TR) may need to increase hundreds of times in order to avoid density problems in cellular network data traffic [1].

Increasing spectral efficiency (SE) in cellular communications is one of the actions to increase area throughput. This term, which expresses the usage efficiency of the unit transmission band, means the number of bits successfully transmitted with each complex valued information sample. Spectral efficiency can increase by increasing some parameters such as the number of active antennas, but these situations generally cause extremely high energy consumption [1]. Nowadays, high energy efficiency (EE) is desired because high energy consumption is not an acceptable situation due to both being harmful to the environment and economic reasons [2]. Expressing the number of successful bits transmitted with unit energy, energy efficiency generally decreases at the points where SE increases, and there is a trade-off between these two values.

It is known that high SE [3-6] and high EE [7-11] levels can be seen using massive multi-input multi-output (massive MIMO) systems, which are known to serve a large number of users by using a large number of antennas. Improvement studies can be made on the trade-off between SE-EE by using Massive MIMO systems [12-13]. There are studies in which some factors (beamforming vector, power allocation etc.) are tried to be optimized in massive MIMO systems [14-17]. Studies to improve the SE-EE trade-off through intelligent optimizations are known [18-20]. There are studies in which the most appropriate values of SE-EE trade-off are determined by accepting some parameters as independent variables for intelligent optimization techniques [2122]. In these studies, SE-EE trade-off is optimized with respect to the transmit power and number of active antennas. In [21] two new methods have been developed from particle swarm optimization (PSO), which are weighted-sum PSO and normal-boundary-intersection PSO, to solve the multi-objective optimization (MOO) problem. In the study linear zero forcing, maximum ratio transmission precoding and random transmit antenna selection are used. In [22] a multi-objective adaptive genetic algorithm (MAGA) is developed in which fitness assignment and mating selection stages have been improved. This algorithm, which relies only on nondominated SE-EE values in the gene pool, has been found to be more successful compared to some other algorithms.

In the rest of the paper, detailed information about the system modelling and the working principle are given in Section 2. Simulation results and evaluation of the obtained results are given in Section 3. Finally inferences made from the results are given in Section 4.

\section{SYSTEM MODEL}

The basic mentality of massive MIMO systems is that the number of active users (K) and the number of active antennas in the cell (M) increases considerably, and consequently, more successful cellular communication is provided. In these systems, it is known that the cellular system can be used in a much more resistant way against intra-cell interference, inter-cell interference and noise by providing the $\mathrm{M}>>1$ and $\mathrm{M}>\mathrm{K}$ conditions [1]. In standard massive MIMO systems, time-division duplex (TDD) is used because this technique requires fewer pilot bits due to its reciprocal nature. Figure 1 shows an example of TDD and an example of a coherence block. Each coherence block contains as many complex-valued samples as multiplied of coherence time $\left(T_{C}\right)$ and coherence bandwidth $\left(B_{C}\right)$.

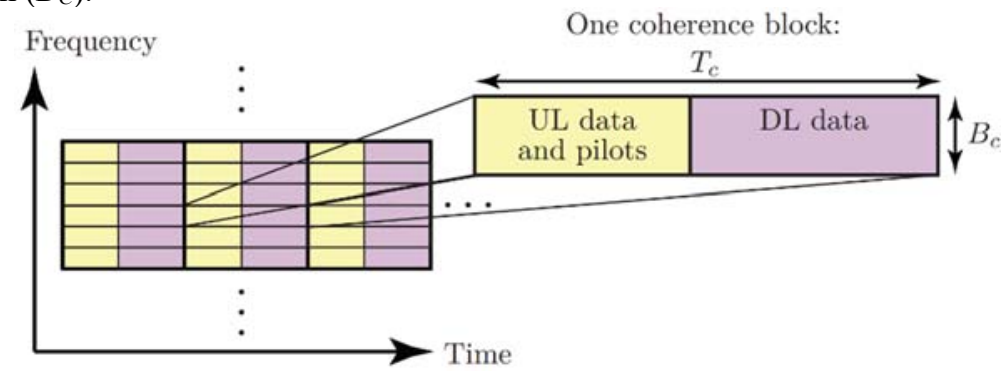

Figure 1. TDD multicarrier modulation scheme [1].

The first step of the calculations of the study is the creation of the arbitrary cells. At this stage, arbitrary cells and correlated Rayleigh fading channels are created according to the instantaneous values of $\mathrm{K}, \mathrm{M}$ and transmission power (p) independent variables as represented in (1): 
$[S E, E E]=\operatorname{Calculate}(K, M, p)$

Then the spatial correlation matrices $(\mathrm{R})$ of these channels are created and the average channel gains are calculated. After these processes, the realization and channel estimations of the channels are made. These data obtained are used in the calculation of spectral efficiency and energy efficiency values. While calculating the instant spectral efficiency, certain ratios of SE values on the uplink (UL) and on the downlink (DL) directions are collected as represented in (2). SE in UL direction represents detecting information signal with a linear acquisition combination whereas SE in DL direction is determined by choosing the larger of the hardening bound or the estimation bound [1].

$$
\mathrm{SE}_{j}=\sum_{k=1}^{\mathrm{K}_{j}}\left(\mathbf{m S E}_{j k}^{\mathrm{UL}}+\mathbf{n} \max \left({\underline{\mathrm{SE}^{\mathrm{DL}}}}_{j k}^{\mathrm{SE}} \mathrm{SE}_{j k}^{\mathrm{DL}}\right)\right)
$$

where $j$ is the number of cells and $k$ is the number of users. $\mathrm{SE}^{\mathrm{DL}}$ represents hardening bound of $\mathrm{SE}$ in $\mathrm{DL}$ direction and $\mathrm{SE}^{\mathrm{DL}}$ represents estimation bound of $\mathrm{SE}$ in $\mathrm{DL}$ direction.

When the SE calculation is complete, the EE value is calculated for the same combination of input parameters. This calculation is as in (3):

$$
\mathrm{EE}_{j}=\frac{\mathrm{TR}_{j}}{\mathrm{ETP}_{j}+\mathrm{CP}_{j}}
$$

Here TR is obtained by multiplying SE with bandwidth $(B)$ and then it is divided by the sum of effective transmit power (ETP) and circuit power (CP) [1]. Circuit power consists the sum of fixed power, transceiver chains power, channel estimation power, coding/decoding power, load-dependent backhaul power and signal processing power.

A databank is created by making calculations for all permutations of independent variables in the specified ranges, and the true Pareto optimal front (POF) of these data is determined. An example of this operations is given in Figure 2. Here, SE and EE pairs calculated for all input values in specified ranges are shown with green curves, while true Pareto optimal front, which is the combination of all non-dominated points, is shown in red. When POF is examined, it is seen that this curve is neither concave nor convex type and whether it increases or decreases in a certain order. It is one of the preferred methods to estimate the Pareto curve by obtaining sample points close to this curve with successful intelligent optimization techniques, instead of complex and long-time determination of this curve, which cannot be obtained with a simple formula.

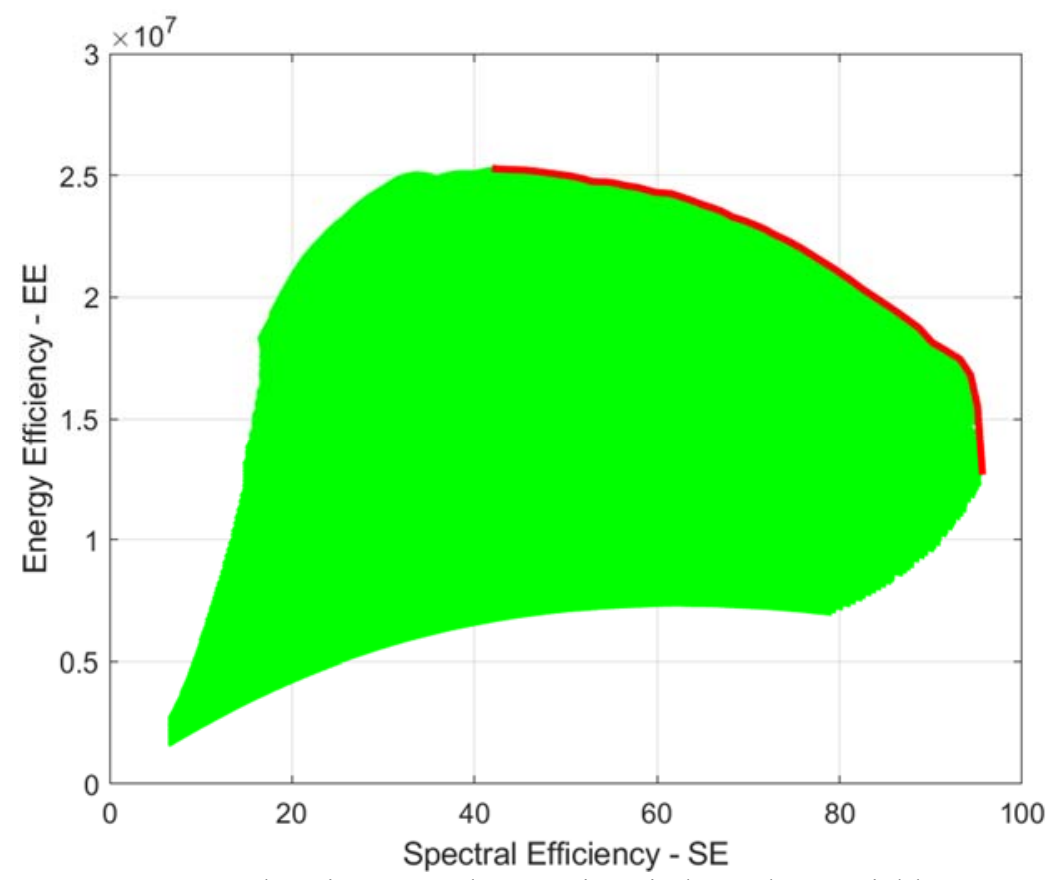

Figure 2. SE-EE values in cases where various independent variables are used.

With usage of intelligent optimizations, without determining all possibilities of the SE-EE trade-off, successful combinations are found so non-dominated SE-EE values are able to be determined in a much shorter time. In this paper, some multi-objective optimizations have been used since SE and EE are tried to be found at the same time. These are the multi-objective genetic algorithm (MOGA), multi-objective particle swarm optimization (MOPSO), and multi-objective differential evolution algorithm (MODEA).

The two basic stages of MOGA are crossover and mutation stages, and these operations are applied with certain probabilities to random elements. In the crossover stage, a new member is tried to be created by hybridizing the 
characteristics of two population members, and then small changes can be made in the mutation stage. After these stages, the detected non-dominated elements are replaced by randomly selected elements from the old population [23].

MOPSO is a herd-inspired optimization that updates all population members at each iteration. Each member finds its next speed, influenced by its previous speed and the speed of the swarm leader. If new solutions that mutate with a certain probability not dominated by the old solutions, they are saved [24].

MODEA updates all members of the population in each iteration. It is based on replacing a random parameter of instant member with the parameter obtained after differential operations applied to three random population members [25].

\section{RESULTS AND DISCUSSION}

The parameters used in the simulations and their values are given in Table 1. As stated in Table 1, the layout of the cells is square pattern so 16 cells are placed in $4 \times 4$ way. The layout of the cells and the arbitrary cell structure are shown in Figure 3.

Table 1. Simulation parameters

\begin{tabular}{cc}
\hline Parameter & Value \\
\hline Network layout & Square pattern (wrap-around) \\
\hline Number of cells & $\mathrm{L}=16$ \\
\hline Cell area & $0.25 \mathrm{~km} \mathrm{x} 0.25 \mathrm{~km}$ \\
\hline Channel gain at 1 km & $\Upsilon=-148.1 \mathrm{~dB}$ \\
\hline Pathloss exponent & $\alpha=3.76$ \\
\hline Shadow fading (standard deviation) & $\sigma_{\mathrm{sf}}=10$ \\
\hline Bandwidth & $B=20 \mathrm{MHz}$ \\
\hline Receiver noise power & $-94 \mathrm{dBm}$ \\
\hline Samples per coherence block & $\tau_{\mathrm{c}}=200$ \\
\hline Pilot reuse factor & $f=1$ \\
\hline
\end{tabular}

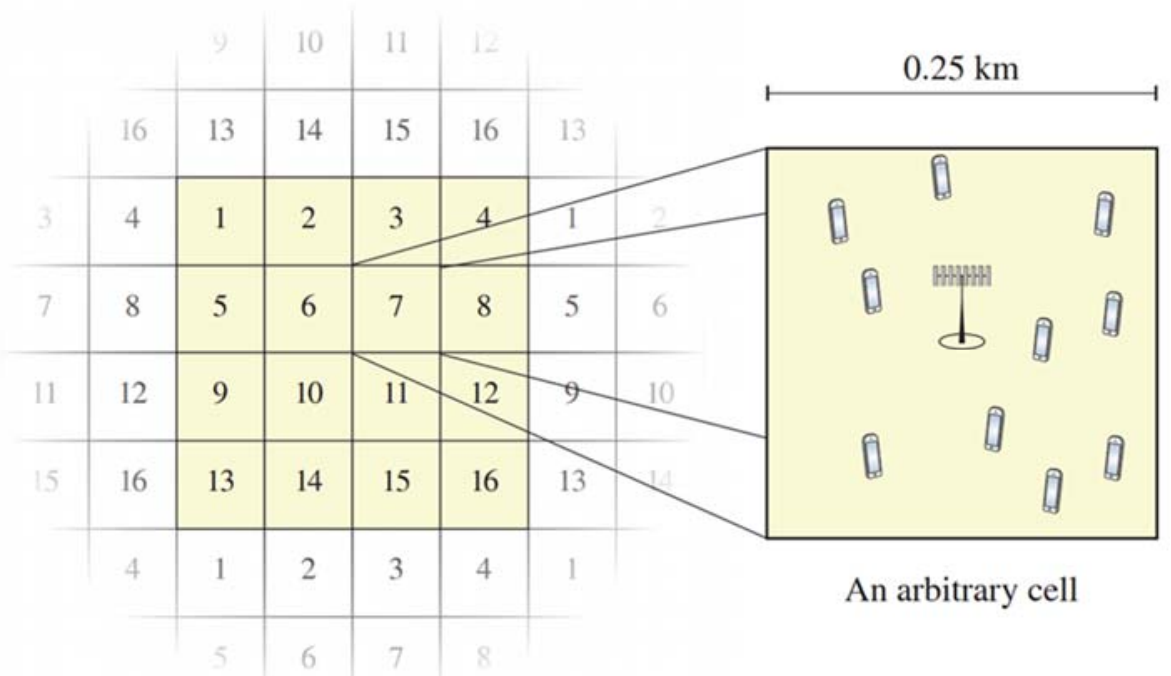

Figure 3. Illustration of cell layouts and an arbitrary cell [1].

Each cell consists of squares with a side length of $0.25 \mathrm{~km}$ and the users are randomly distributed within the cell. After all users are placed within more than 35 meters of each other and the base station (BS), the calculation process is started. The boundaries of $\mathrm{K}$ and $\mathrm{M}$ are defined as 10-100 and boundaries of $\mathrm{p}$ are defined as 50-200 $\mathrm{mW}$. Proportions of SE for uplink direction and for downlink direction were chosen as $1 / 3$ and 2/3, respectively. In order to examine the effects of circuit power parameters on energy efficiency, three power sets given in Table 2 were used. 
Table 2. Values of circuit power sets

\begin{tabular}{cccc}
\hline Parameter & Set 1 & Set 2 & Set 3 \\
\hline Fixed power: $P_{\mathrm{FIX}}$ & $10 \mathrm{~W}$ & $5 \mathrm{~W}$ & $5 \mathrm{~W}$ \\
\hline Power for BS local oscillator: $P_{\mathrm{LO}}$ & $0.2 \mathrm{~W}$ & $0.1 \mathrm{~W}$ & $0.1 \mathrm{~W}$ \\
\hline Power per BS antennas: $P_{\mathrm{BS}}$ & $0.4 \mathrm{~W}$ & $0.2 \mathrm{~W}$ & $0.2 \mathrm{~W}$ \\
\hline Power per user equipment: $P_{\mathrm{UE}}$ & $0.2 \mathrm{~W}$ & $0.1 \mathrm{~W}$ & $0.1 \mathrm{~W}$ \\
\hline Power for data encoding: $P_{\mathrm{COD}}$ & $0.1 \mathrm{~W} /(\mathrm{Gbit} / \mathrm{s})$ & $0.01 \mathrm{~W} /(\mathrm{Gbit} / \mathrm{s})$ & $0.03 \mathrm{~W} /(\mathrm{Gbit} / \mathrm{s})$ \\
\hline Power for data decoding: $P_{\mathrm{DEC}}$ & $0.8 \mathrm{~W} /(\mathrm{Gbit} / \mathrm{s})$ & $0.08 \mathrm{~W} /(\mathrm{Gbit} / \mathrm{s})$ & $0.24 \mathrm{~W} /(\mathrm{Gbit} / \mathrm{s})$ \\
\hline BS computational efficiency: $L_{\mathrm{BS}}$ & $75 \mathrm{Gflops} / \mathrm{W}$ & $250 \mathrm{Gflops} / \mathrm{W}$ & $150 \mathrm{Gflops} / \mathrm{W}$ \\
\hline Power for backhaul traffic: $P_{\mathrm{BT}}$ & $0.25 \mathrm{~W} /(\mathrm{Gbit} / \mathrm{s})$ & $0.025 \mathrm{~W} /(\mathrm{Gbit} / \mathrm{s})$ & $0.075 \mathrm{~W} /(\mathrm{Gbit} / \mathrm{s})$ \\
\hline
\end{tabular}

The intelligent optimization techniques, which are used to identify suitable solutions on SE and EE trade-offs, have a population of 100 elements and make 50 iterations. For power set 1, the energy efficiency versus spectral efficiency for MOGA, MOPSO and MODEA is given in Figure 4a, Figure 4b and Figure 4c, respectively. For power set 2, the energy efficiency versus spectral efficiency for MOGA, MOPSO and MODEA is given in Figure 5a, Figure $5 \mathrm{~b}$ and Figure 5c, respectively. For power set 3, the energy efficiency versus spectral efficiency for MOGA, MOPSO and MODEA is given in Figure 6a, Figure $6 \mathrm{~b}$ and Figure $6 \mathrm{c}$, respectively. In order to be a reference point for optimization results, the calculated curves for all independent variable permutations are shown in green, and the ideal true POF for these values is shown in red. Non-dominated values determined through intelligent optimizations are marked with black asterisks.

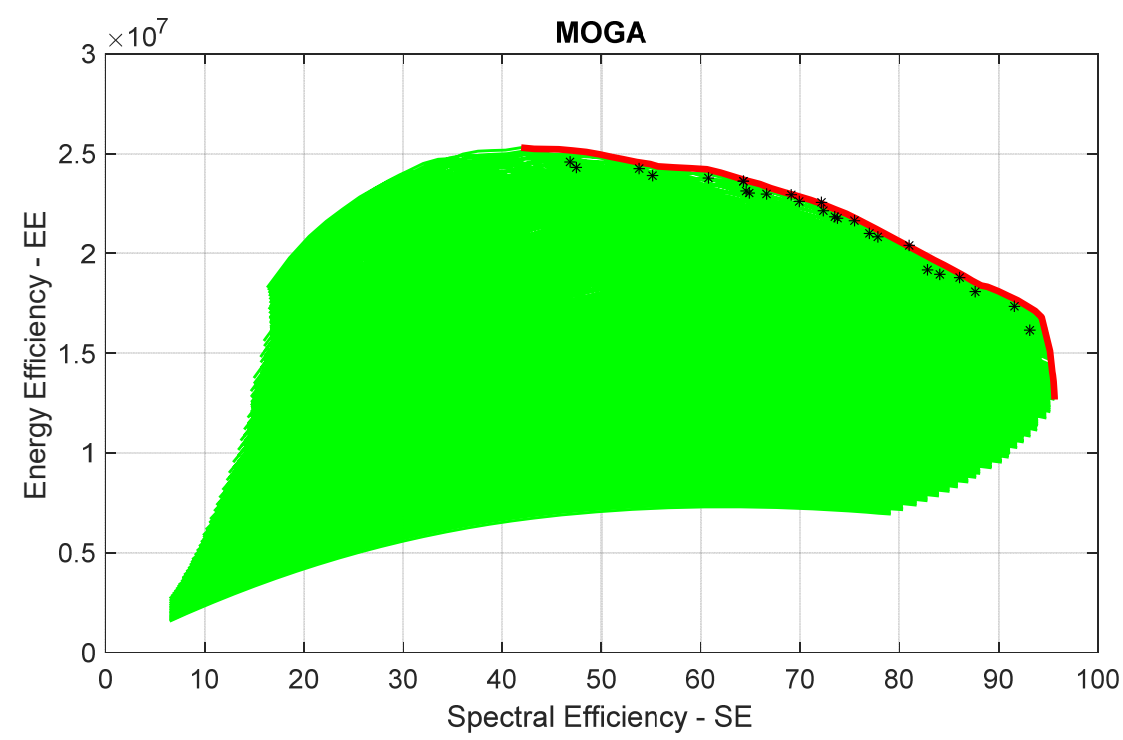

Figure 4a. Comparing true POF and performance of MOGA on power set 1.

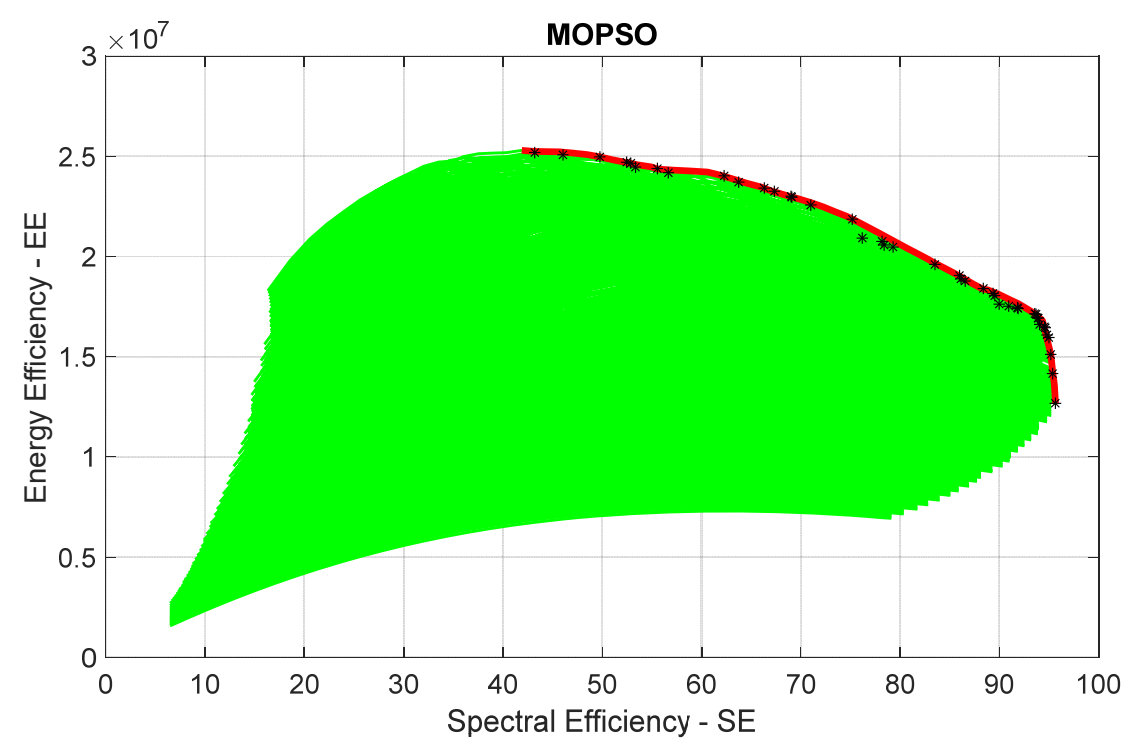

Figure 4b. Comparing true POF and performance of MOPSO on power set 1. 


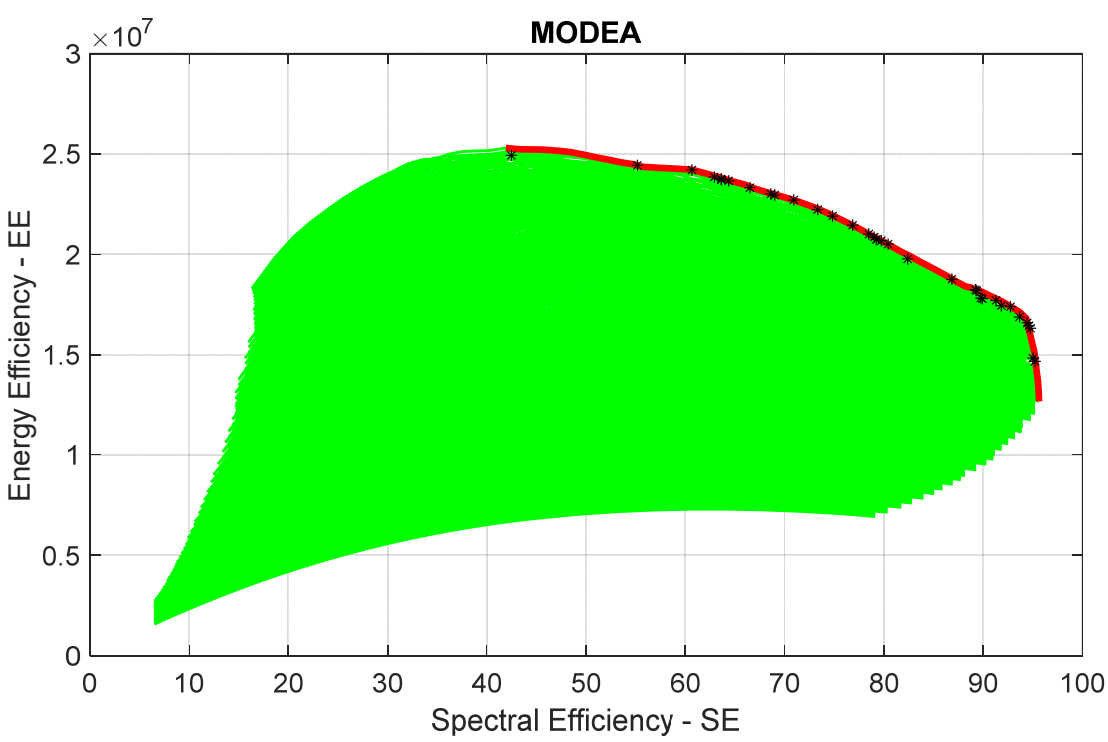

Figure 4c. Comparing true POF and performance of MODEA on power set 1.

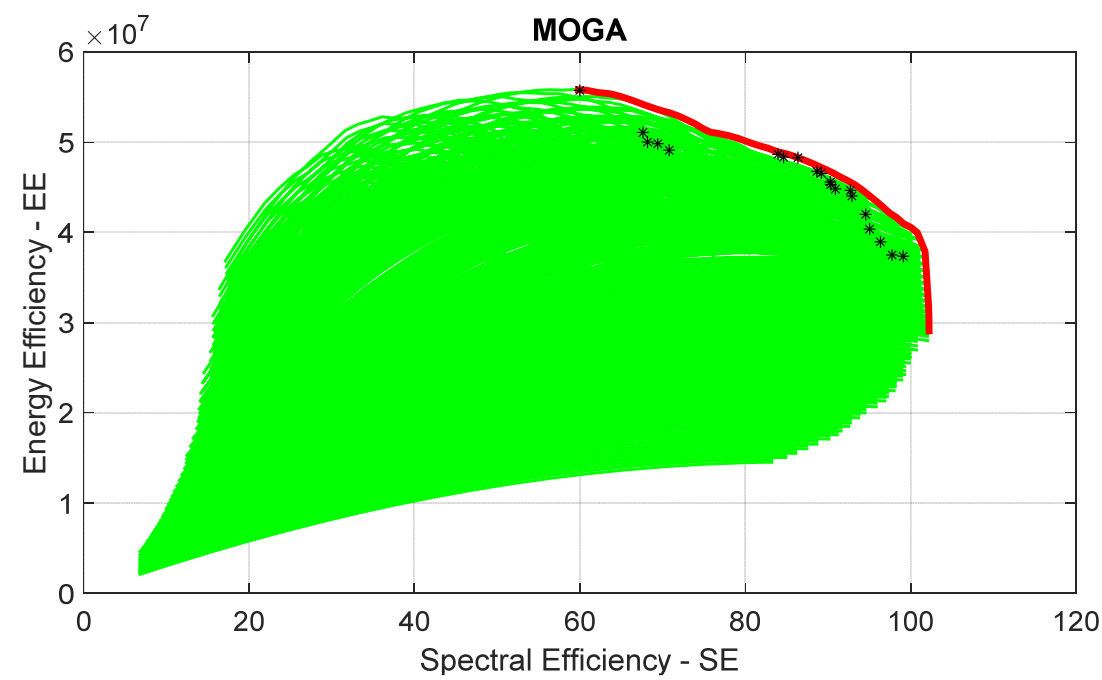

Figure 5a. Comparing true POF and performance of MOGA on power set 2.

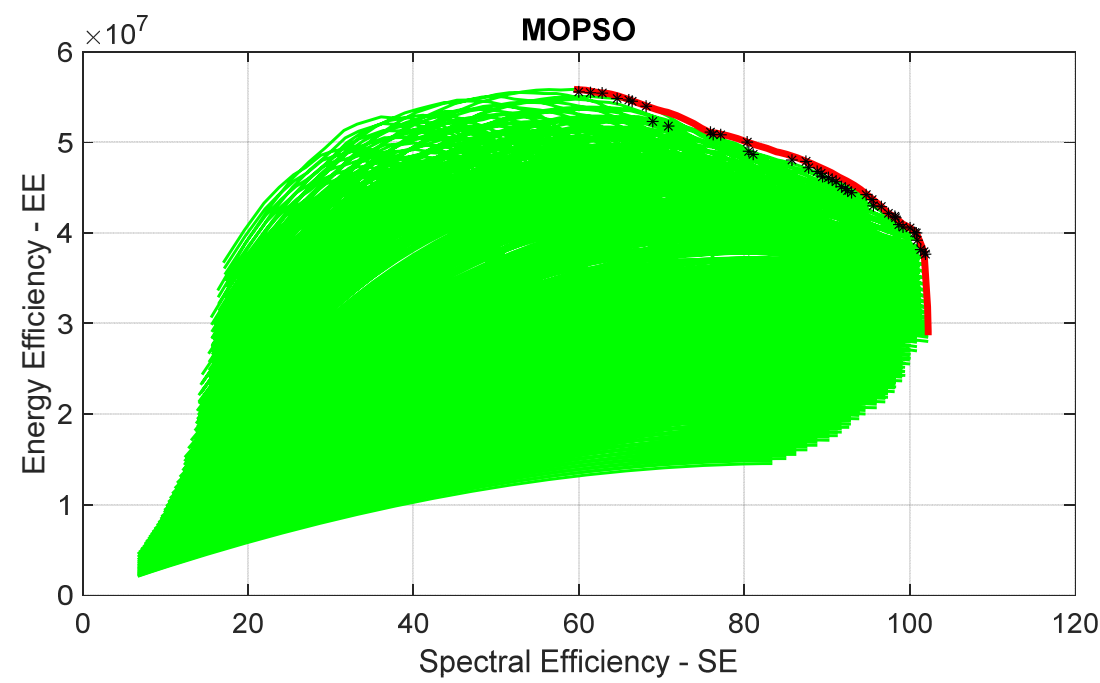

Figure 5b. Comparing true POF and performance of MOPSO on power set 2. 


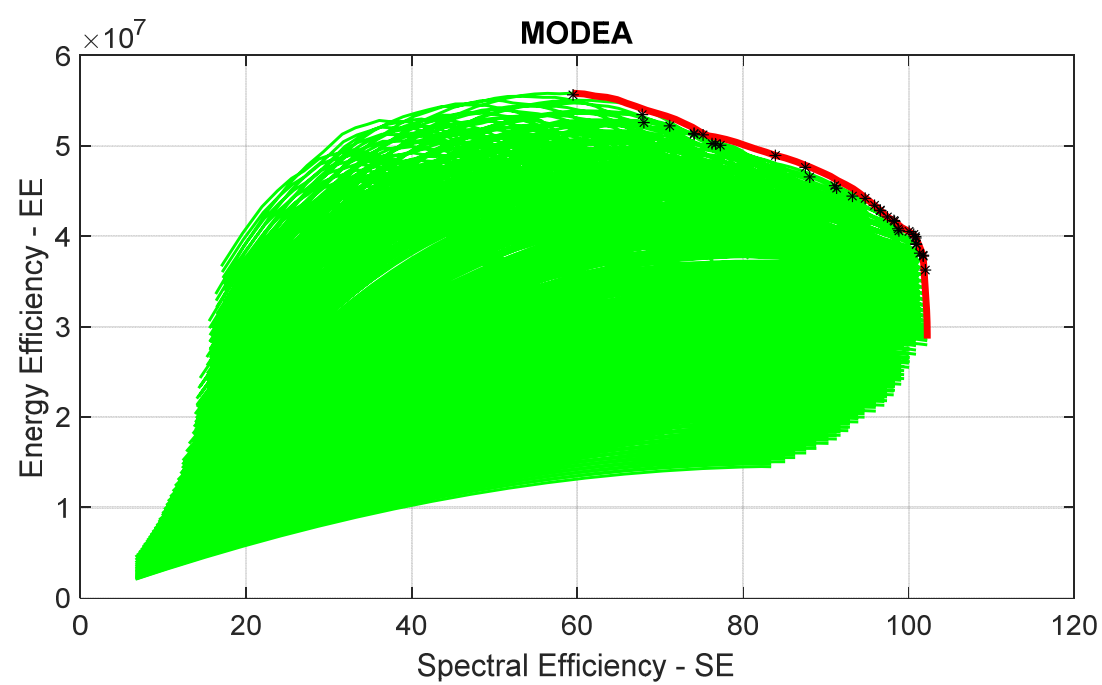

Figure 5c. Comparing true POF and performance of MODEA on power set 2.

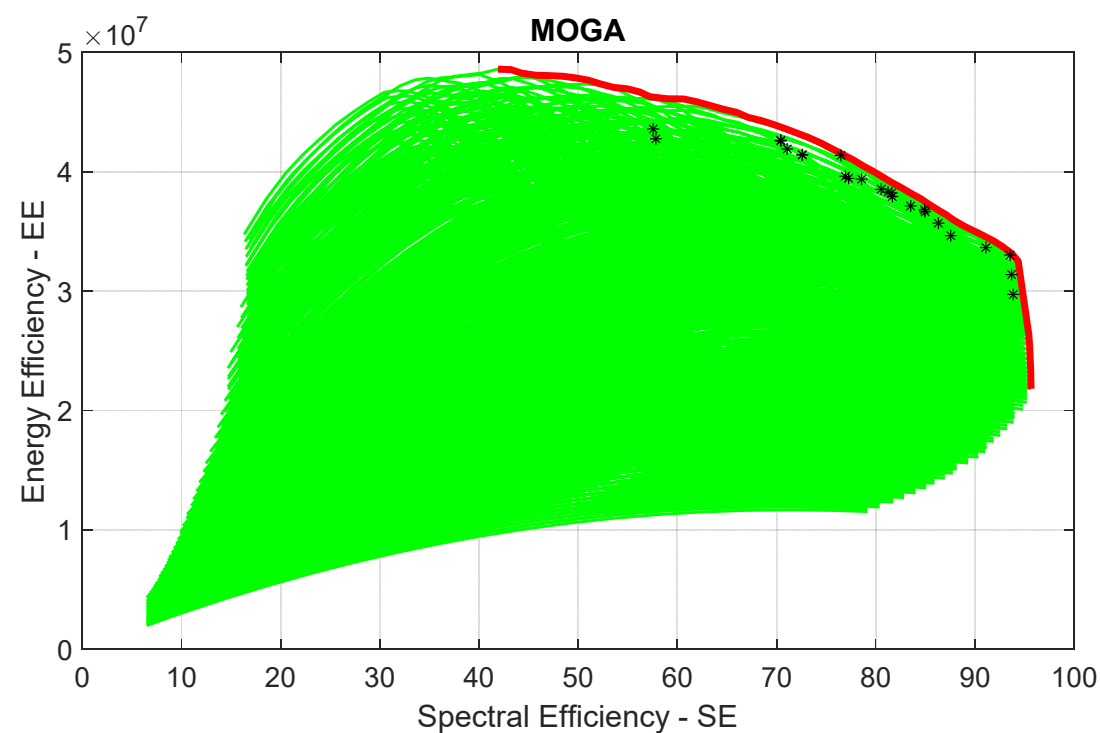

Figure 6a. Comparing true POF and performance of MOGA on power set 3.

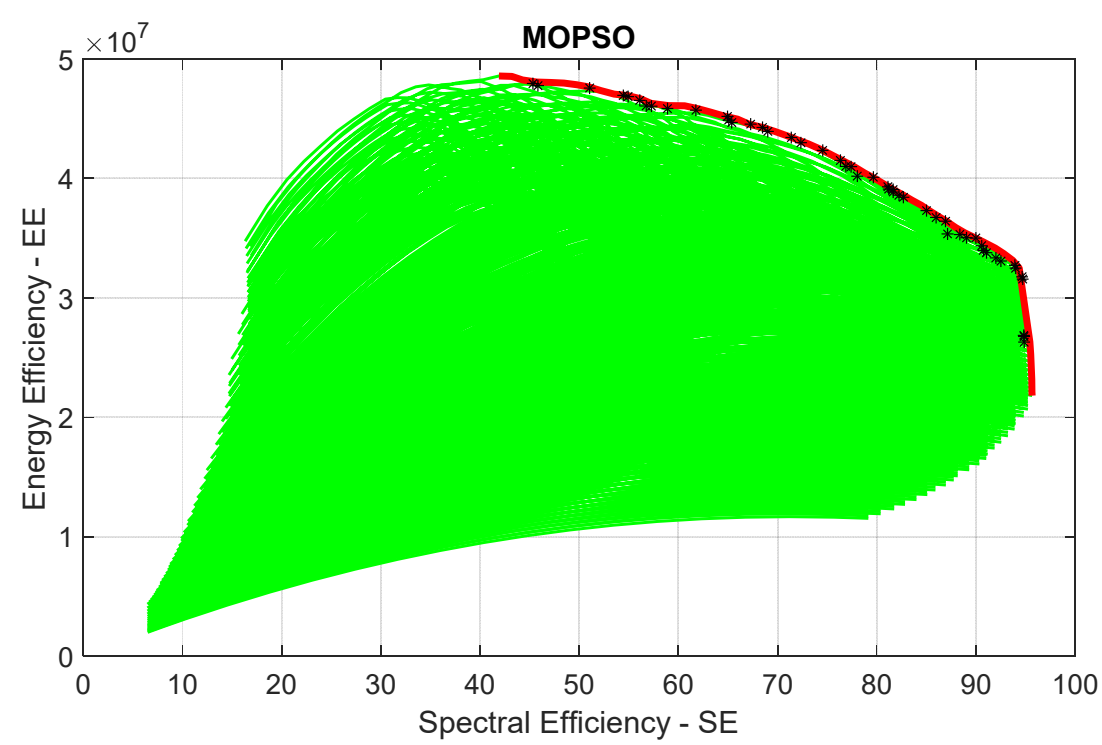

Figure 6b. Comparing true POF and performance of MOPSO on power set 3. 


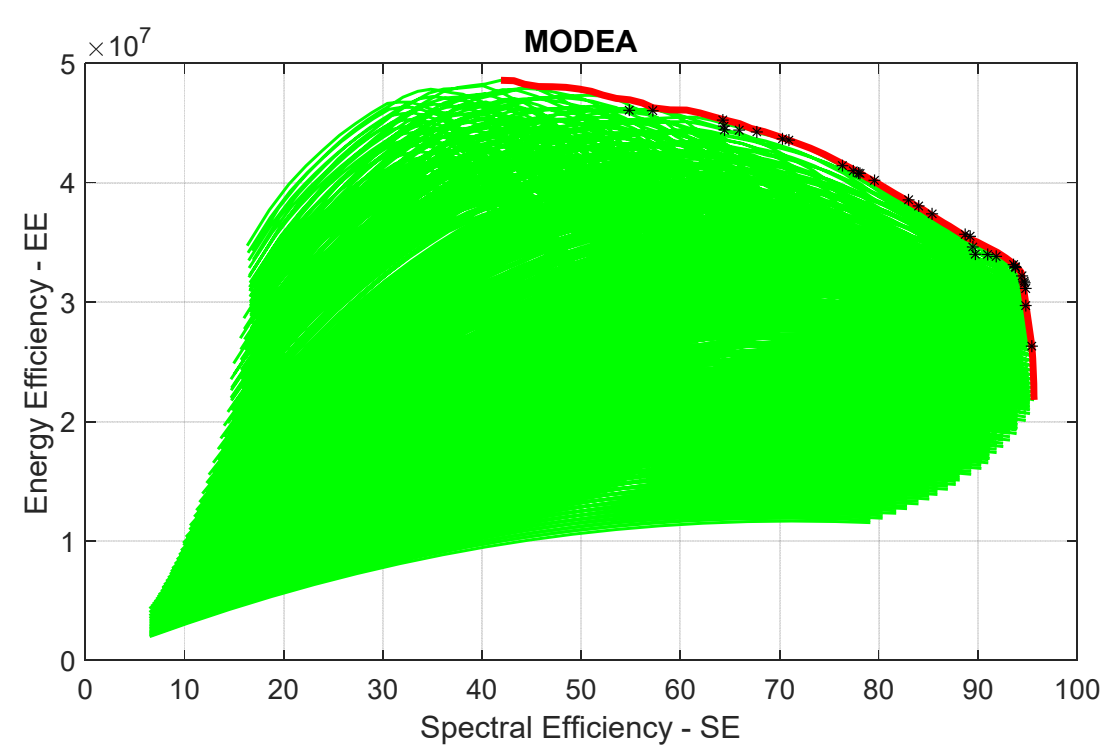

Figure 6c. Comparing true POF and performance of MODEA on power set 3.

When Figures 4, 5 and 6 are examined, it is seen that some SE-EE values can be detected around the true POF via intelligent optimizations. When the figures are examined in detail, it is seen that each algorithm can find the solutions with different characteristics (balanced distribution on true POF, etc.) by different success. Performance metrics were calculated in inverted generational distance (IGD), maximum spread (MS) and spacing metric (S) criteria to examine the success of algorithms in different areas. IGD represents the distance of the predicted Pareto curves to the true Pareto curves, MS means the overlap between the predicted Pareto and true POF, and S means the distances of the two consecutive solutions to each other. While IGD and S are expected to be low, MS is desired to be high. Table 3 shows the performance metrics of the algorithms on different circuit power sets.

Table 3. Comparison of the performance metrics

\begin{tabular}{|c|c|c|c|c|}
\hline & Algorithm & IGD & MS & $\mathbf{S}$ \\
\hline \multirow{3}{*}{$\overrightarrow{\bar{r}}$} & MOGA & $7,78^{*} 10^{5}$ & 0,77 & $4,12 * 10^{5}$ \\
\hline & MOPSO & $1,50 * 10^{5}$ & 0,94 & $4,30 * 10^{5}$ \\
\hline & MODEA & $3,85 * 10^{5}$ & 0,91 & $2,83 * 10^{5}$ \\
\hline \multirow{3}{*}{$\underset{ }{N}$} & MOGA & $1,53 * 10^{6}$ & 0,81 & $1,45^{*} 10^{6}$ \\
\hline & MOPSO & $1,25 * 10^{6}$ & 0,85 & $3,47 * 10^{5}$ \\
\hline & MODEA & $1,12 * 10^{6}$ & 0,87 & $6,46^{*} 10^{5}$ \\
\hline \multirow{3}{*}{$\frac{m}{\sqrt{2}}$} & MOGA & $2,31 * 10^{6}$ & 0,78 & $6,25 * 10^{5}$ \\
\hline & MOPSO & $6,38 * 10^{5}$ & 0,87 & $6,47 * 10^{5}$ \\
\hline & MODEA & $9,96 * 10^{5}$ & 0,75 & $9,78^{*} 10^{5}$ \\
\hline
\end{tabular}

Figure 7 shows the variations of the numbers of non-dominated solutions versus the number of iterations on power set 1 for algorithms used in simulations. When the figure is examined, it is seen that the algorithms' tendencies to find non-dominated solutions differ. For example, it is seen that while MOGA shows a fluctuating trend, MOPSO generally increases at the same rate. 


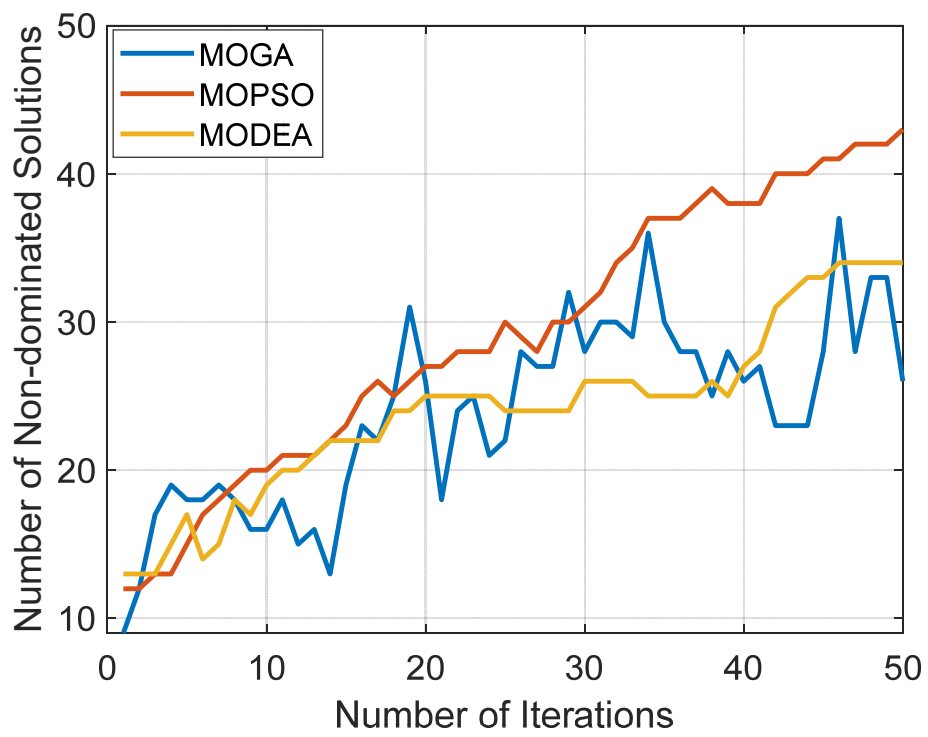

Figure 7. The variations of the numbers of non-dominated solutions versus the number of iterations for algorithms used in simulations.

\section{CONCLUSION}

Compared to finding all spectral and energy efficiency values and then determining true POF, simulating Pareto curve with intelligent optimizations involves very little operation. With a sufficient number of samples, an acceptable level of successful Pareto curve could be obtained. When the simulation results are examined, the most successful results are obtained on power set 1 . When the algorithms are compared, it is seen that MOPSO has generally obtained more successful results in the three criteria mentioned and found a greater number of nondominated SE-EE values.

Statement of Conflict of Interest: Author has declared no conflict of interest.

Author's Contributions: The contribution of the authors is equal

\section{REFERENCES}

[1] E. Björnson, J. Hoydis, and L. Sanguinetti, "Massive MIMO Networks: Spectral, Energy and Hardware Efficiency", Foundation and Trends in Signal Processing, pp. 154-655, 2017.

[2] A. Fehske, G. Fettweis, J. Malmodin, and G. Biczok, "The Global Footprint of Mobile Communications: The Ecological and Economic Perspective", IEEE Transactions on Wireless Communications, 49(8), pp. 55-62, 2011.

[3] W. Tan, S. Jin, and C. K. Wen, "Spectral efficiency of multi-user millimeter wave systems under single path with uniform rectangular arrays", J Wireless Com Network, 181, pp. 1-13, 2017.

[4] W. B. Hasan, P. Harris, A. Doufexi, and M. Beach, "Real-time maximum spectral efficiency for massive MIMO and its limits", IEEE Access 6, pp. 4612246133, 2018.

[5] H. Pirzadeh, and A. L. Swindlehurst, "Spectral efficiency of mixed-ADC massive MIMO", IEEE Transactions on Signal Processing 66(13), pp. 35993613, 2018.

[6] Q. Lv, J. Li, P. Zhu, and X. You, "Spectral Efficiency Analysis for Bidirectional Dynamic Network with Massive MIMO Under Imperfect
CSI", IEEE Access 6,8421208, pp. 43660-43671, 2018.

[7] H. Q. Ngo, E. Larsson, and T. Marzetta, "Energy and spectral efficiency of very large multiuser MIMO systems", IEEE Trans Commun 61(4), pp. 1436-1449, 2013.

[8] J. Fan, and Y. Zhang, "Energy efficiency of massive MU-MIMO with limited antennas in downlink cellular networks", Digit Signal Process 86, pp. 1$10,2019$.

[9] E. Sharma, R. Budhiraja, K. Vasudevan, and L. Hanzo, "Full-Duplex Massive MIMO Multi-Pair Two-Way AF Relaying: Energy Efficiency Optimization", IEEE Transactions on Communications 66(8),8329521, pp. 3322-3340, 2018.

[10] H. Q. Ngo, L-N. Tran, T. Q. Duong, M. Matthaiou, and E. G. Larsson, "Energy Efficiency Optimization for Cell-Free Massive MIMO", IEEE Workshop on Signal Processing Advances in Wireless Communications, SPAWC 8227722, pp. 1-5, 2017.

[11] D. Chen, F. Liu, C. Feng, J. Shi, and X. Han, "Energy Efficiency Optimization Based Selfinterference Cancellation in Massive MIMO Full- 
duplex System" IEEE/CIC International Conference on Communications in China (ICCC), Qingdao, pp. $1-6,2017$.

[12] Y. Huang, S. He, J. Wang, and J. Zhu, "Spectral and Energy Efficiency Tradeoff for Massive MIMO", IEEE Transactions on Vehicular Technology, vol. 67, no. 8, pp. 6991-7002, 2018.

[13] Y. Xin, D. Wang, J. Li, H. Zhu, J. Wang and X. You, "Area Spectral Efficiency and Area Energy Efficiency of Massive MIMO Cellular Systems", IEEE Transactions on Vehicular Technology, vol. 65, no. 5, pp. 3243-3254, 2016.

[14] O. Amin, E. Bedeer, M. H. Ahmed and O. A. Dobre, "Energy Efficiency-Spectral Efficiency Tradeoff: A Multiobjective Optimization Approach", IEEE Transactions on Vehicular Technology, vol. 65, no. 4, pp. 1975-1981, 2016.

[15] L. Deng, Y. Rui, P. Cheng, J. Zhang, Q. T. Zhang and M. Li, "A Unified Energy Efficiency and Spectral Efficiency Tradeoff Metric in Wireless Networks", IEEE Communications Letters, vol. 17, no. 1, pp. 55-58, 2013.

[16] L. You, J. Xiong, A. Zappone, W. Wang and X. Gao, "Spectral Efficiency and Energy Efficiency Tradeoff in Massive MIMO Downlink Transmission With Statistical CSIT", IEEE Transactions on Signal Processing, vol. 68, pp. 2645-2659, 2020.

[17] O. Amin, E. Bedeer, M. H. Ahmed and O. A. Dobre, "Energy efficiency and spectral efficiency trade-off for OFDM systems with imperfect channel estimation", IEEE International Conference on Communications (ICC), pp. 3553-3558, 2014.

[18] S. M. Nimmagadda, "Optimal spectral and energy efficiency trade-off for massive MIMO technology: analysis on modified lion and grey wolf optimization", Soft Comput 24, pp. 12523-12539, 2020.
[19] K. E. Purushothaman, and V. Nagarajan, "Multiobjective optimization based on selforganizing Particle Swarm Optimization algorithm for massive MIMO 5G wireless network", International Journal of Commun Systems, e4725, pp. 1-15, 2020.

[20] S. Cetinkaya and H. Arslan, "A Distributed UserCell Association for Spectral and Energy Efficiency Tradeoff in Massive MIMO UDHNs", IEEE 30th Annual International Symposium on Personal, Indoor and Mobile Radio Communications (PIMRC), pp. 1-6, 2019.

[21] Z. Liu, W. Du and D. Sun, "Energy and Spectral Efficiency Tradeoff for Massive MIMO Systems With Transmit Antenna Selection", IEEE Transactions on Vehicular Technology, vol. 66, no. 5, pp. 4453-4457, 2017.

[22] Y. Hei, C. Zhang, and W. Song, "Energy and spectral efficiency tradeoff in massive MIMO systems with multi-objective adaptive genetic algorithm", Soft Comput 23, pp. 7163-7179, 2019.

[23] T. Murata, and H. Ishibuchi, "MOGA: Multiobjective genetic algorithms", Proc. of 1995 IEEE International Conference on Evolutionary Computation, pp. 289-294, 1995.

[24] C. A. C. Coello, G. T. Pulido, and M. S. Lechuga, "Handling multiple objectives with particle swarm optimization", in IEEE Transactions on Evolutionary Computation, vol. 8, no. 3, pp. 256279, 2004.

[25] W. Gong, and Z. Cai, "A multiobjective differential evolution algorithm for constrained optimization", IEEE Congress on Evolutionary Computation, pp. 181-188, 2008. 